IRSH 65 (2020), pp. 579-59I doi:I0.1017/S002085902000053X

(C) 2020 Internationaal Instituut voor Sociale Geschiedenis

\title{
GUIDE TO THE INTERNATIONAL ARCHIVES AND COLLECTIONS AT THE IISH: SUPPLEMENT FOR 2019*
}

In I999, a revised edition of the 1989 Guide to the International Archives and Collections at the IISH, Amsterdam (hereafter GIA) was published. This was the last printed GIA. From I 998 onwards, annual supplements to this GIA have been published in Issue 2 of the International Review of Social History (IRSH). This year, due to restrictions caused by the Covid-I 9 pandemic, publication of the GIA was postponed to Issue 3 .

In recent years, all information on archival holdings at the IISH has become available online and appears in the institute's online catalogue under search.socialhistory.org. In addition to listing papers and archives, this catalogue features descriptions of collections containing audiovisual and library materials. Audiovisual materials include audio cassettes, videos, photographs, slides, negatives, and posters. Library materials include books, periodicals, and brochures.

The archives may be consulted in the IISH reading room in Amsterdam and increasingly online as well. Requests for access to the physical documents or for digital reproductions may be submitted via the online catalogue. For additional information about rules for access and consultation (including procedures for handling the material and making photocopies), please consult the website socialhistory.org/en/services or contact the IISH information service (e-mail: ask@iisg.nl).

Each entry offers a summary comprising the following:

I. Access: As a rule, consultation is not restricted; any restrictions are indicated by *.

2. Name: Names of persons include dates of birth and death, when known. In the case of international organizations with names in more than one language, the language is selected in which most of the documents were written. For organizations that have changed their names, the name used most recently is selected. Previous names of organizations are mentioned in the condensed history. The names of subject collections are mostly in English.

3. Period: First and last date of the documents present. Where only a few documents are from a certain year or period, they are listed in parentheses.

\footnotetext{
* Edited by Bouwe Hijma.
} 
4. Size: In linear metres.

5. Finding aid: Available inventories, lists, and indexes.

6. Biography/history: A condensed biography or history of the persons or organizations concerned.

7. Summary of contents: A summary of the contents of the archives, papers, or collection concerned.

In the case of an accrual to existing archives, a reference appears to the 'url' containing the initial description as well as the supplement(s).

\section{Persons}

Federn, Etta (I883-I95I) - Papers

Period: 1932, I935, I944-1945, I947-195 I

Size: $0.0 \mathrm{I} \mathrm{m}$.

Finding aid: inventory

Marietta (Etta) Federn; born in Vienna, Austria, 28 April I 883, died in Paris, France, 9 May I95 I; Austrian writer, translator, and anarcho-syndicalist activist; raised in Vienna in an assimilated Jewish family from Prague; studied in Vienna and Berlin and obtained her PhD on a study on Faust; married the pedagogue Max Kirmsse and after her divorce the painter Peter Paul Kohlhaas; joined a circle of anarchists that included Rudolf Rocker and Emma Goldman; published Sein Leben und Wirken, a biography of Walther Rathenau I927; after death threats fled to Spain with her two sons 1932; after the bombing of Barcelona in 1938 left for France, where she went into hiding in a monastery near Lyon from 1940 until the end of the war.

Letters from Etta Federn-Kohlhaas to George Pick and his wife Frieda R. Pick 1932, their son Grant Pick I95 I and their family secretary Mrs. Hutchinson I935, I944-1945, I948; correspondence and other documents about financial aid to Etta Federn living in Paris I944-1945, I947-195 I; letter from Michel Kohlhaas-Federn to Grant Pick about the death of his mother Etta Federn I95I.

N.B. Papers are part of http://hdl.handle.net/10622/ARCHoI77I.

Holz, Hans Heinz (1927-20I I) - Papers

Period: $1982-2010$

Size: $3 \mathrm{~m}$.

Finding aid: inventory

Born in Frankfurt am Main, Germany, 26 February 1927, died in Sant'Abbondio, Switzerland, I I December 20I I; active in the German resistance during World War II, imprisoned by the Gestapo; studied philosophy; worked as a journalist in Germany, at the newspaper Deutsche Woche and at the Hessische Rundfunk, but also 
in Switzerland; his first attempt to get his $\mathrm{PhD}$ with the dissertation "Die Selbstinterpretation des Seins" failed because of his political fight with Gottfried Martin, the successor to his original promoter Otto Friedrich Bollnow at the University of Mainz; a second attempt to get his degree at the University of Leipzig with the dissertation "Herr und Knecht bei Leibniz und Hegel" failed because his promoter Ernst Bloch fell into disgrace with the authorities of the GDR; eventually awarded his PhD in 1969; professor at the University of Marburg, Germany 197 I-1979; professor at the University of Groningen, the Netherlands, where he worked with Ger Harmsen, 1979-I 993; active member of the Deutsche Kommunistische Partei (DKP), especially in the commissions, formulating a new party programme that resulted in the adoption of this programme at the 17th Parteitag (party congress) 1995-2008.

Documents regarding the various programme commissions of the DKP, especially the Arbeitsgruppe with the four members Willi Gerns, Nina Hager, Hans Heinz Holz, and Leo Mayer, and the formulating of a new party programme 1995-2006; documents on the 16th Parteitag in 2002 and the 17th Parteitag in 2005-2006; documents on his retirement as an active member of the party 2008 .

\section{Malouvier, Guy (born 1938) - Papers \\ Period: 1924-2007 \\ Size: $3.47 \mathrm{~m}$. \\ Finding aid: inventory}

Guy Malouvier [Guy Ségur, Gui Maslobièr]; born in Malakoff (Seine-et-Oise), France, Is January 1938; studied economics; became an anarchist under the influence of CNT-FAI while studying at the University of Barcelona 1959-1960; military service in Algeria where he performed his military duty during the Algerian War of Independence; maintained contacts there with the Front de Libération Nationale (FLN); back in France joined a local group of the Fédération Anarchiste Française (FAF), presided over by Robert Pannier, in his hometown of Montreuil; contributed as a writer of articles and translator to Le Monde Libertaire, the FAF monthly; worked in various bookshops and publishing houses as a proofreader or editor from 1963 to the early 1980s; activist from 1967 within the Organisation Révolutionnaire Anarchiste (ORA), which became the French section of the Internationale des Féderations Anarchistes (IFA); left the FAF after a rupture at its congress in Marseille I968 and left the ORA I97I; co-founder of the Fédération Anarchiste Communiste d'Occitanie (FACO) I97I; gradually withdrew from active politics in the late I970s and concentrated on research into the history and documentation of Anarchist movements and, in particular, their Jewish branches, reflecting a growing interest in Jewish Studies; alongside his political activities he was editor-in-chief of the surrealist literary magazine Le Puits de l'Ermite; worked in various companies in the metal industry in the Paris region from 1983 until his retirement in 1999.

Correspondence of the Fédération Anarchiste Française (FAF) with the Groupe de Montreuil, the Comité de Lecture du Monde Libertaire (ML), 
the Secrétariat aux Relations Internationales (SARI), the Commission Préparatoire du Congrès International de Fédérations Anarchistes, and the Comité de Relations de l'Internationale de Fédérations Anarchistes (CRIFA) I963-I97I; circular letters, reports on activities, and other documents from the FAF 1948-1969; documents on the FAF congress in Marseille 1968-1969; documents from the Commission de Relations Internationales Anarchistes (CRIA) 1947-1956; documents from the Commission de Relations de l'Internationale de Fédérations Anarchistes (CRIFA) 1966-1973; correspondence and other documents on national and regional libertarian movements in various countries I966-I 973; minutes of meetings, correspondence, internal bulletins, reports from the Organisation Révolutionnaire Anarchiste (ORA) 1967-I976; correspondence, circular letters, and other documents from the Fédération Anarchiste-Communiste d'Occitanie (FACO) I970-1975; letters from Boris Yelensky to Jacques Doubinsky 1945-1958; correspondence and other documents regarding the Alexander Berkman Political Refugee Fund 1944-1950; biographical typescripts on the lives of Meir Blankstein and his life companion Hannah Blankstein n.d., typescript by Meir Blankstein on Israel [1950] and a letter from Guy Malouvier to René Bianco on this couple, their eventful life, and these typescripts I995; handwritten testimonies of the May events in 1968; correspondence and typescripts regarding the bulletin Anarchives and the Cabiers Max Nettlau 1978-198I; correspondence, notes, and typescripts on Eugen Relgis and Rudolf Rocker, the Jewish anarchist movement, and the history of anarchism 1968-1996; correspondence, manuscripts, and other documents regarding the literary magazine Le Puits de l'Ermite 1964-1979; manuscripts of articles and translations for Le Monde Libertaire 1964-1967.

\section{Melo, Hector Enrique (died 1999) - Papers \\ Period: 1986-I999 \\ Size: I.I $2 \mathrm{~m}$.}

\section{Finding aid: inventory}

Born in Colombia, died I7 August 1999; worked as an economist and journalist before political and personal pressure resulting from his writings promoted his departure from Colombia; moved to the United States 1987 and settled in New Paltz, New York; completed a master's degree in Latin American Studies at Columbia University in New York under Herbert Klein; went to Northeastern University in Boston to work in the programme on Latino, Latin American, and Caribbean Studies 1996; entered the Ph.D. programme in world history at Northeastern University under Patrick Manning in spring 1999; began an innovative dissertation on modern migration throughout Latin America; had a long history of problems and discussions with the immigration authorities, not yet resolved in I999; died of a heart attack in the summer of that year. 
The documents, filed carefully by his colleagues after his death, include photocopies of publications documenting changes in administrative boundaries in Latin American and Caribbean nations in Igth and 2oth centuries; population and health statistics for Latin American countries, I 9 th and 20 th centuries; foreign trade statistics for Latin American and Caribbean countries, I9th and 2oth centuries; collections - mostly bound - of articles on Latin American and world history by Hector Melo and other writers; also included - interspersed with the photocopies - are numerous handwritten lists of data, meant and prepared to link and correct the published data.

\section{Michel, Detlef (born 1944) - Papers \\ Period: $1960-1970$ \\ Size: $0.25 \mathrm{~m}$.}

Finding aid: inventory

Born in Turckheim, Germany, 26 May I944; author; raised in Berlin and Braunschweig; studied in Tübingen, Munich, and Berlin; member of the Sozialistischer Deutscher Studentenbund (SDS) 1964-1970; participated, as a member of the Kritische Universität, in the preparations of the Springer Tribunal; was a member of Kommune I for a short period at its beginning; employed at the University of Osnabrück 19761979; editor of the Berliner Hefte 1976-1982; professor at the Deutsches Literaturinstitut of the University of Leipzig 200I-2002; author for the Reichskabarett, a satirical student cabaret in Berlin, I966-1970, and the Grips-Theater 1975-1989; author of various film scenarios; member of the PEN Zentrum Deutschland from 1997 and member of the Deutsche Filmakademie from 2003.

Minutes of meetings, circular letters, leaflets, and other documents from the federal organization and the regional Berlin department of the Sozialistischer Deutscher Studentenbund (SDS) 1964-1969; files on the Springer Verlag (Publishing House) and the Springer Tribunal in Berlin, prepared by the SDS and the Kritische Universität (Critical University), including letters from Günther Anders, Fritz Bauer, Gerd Bucerius, Thomas Ellwein, Karl-Hermann Flach, Ossip Flechtheim, Heinrich Hannover, Werner Hofmann, Ulrich Klug, and Alexander Mitscherlich (1960) I965I968.

N.B. See for the context of Michel papers the websites of the Infopartisan project and the Süddeutsche Zeitung and, in particular, in the brochure Der Untergang der Bild-Zeitung, the detailed explanation by Dietmar Kesten on the website www.mao-projekt.de. 


\section{Pablo, Michel (Raptis) (I9I I-I996) - Audio Collection \\ Period: 1995 and n.d. \\ Size: I I.4 I GB, I 28 files}

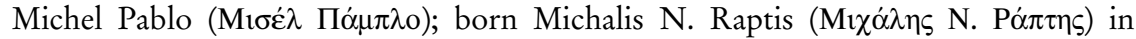
Alexandria, Egypt, 24 August 191 I, died in Athens, Greece, I7 February 1996; Trotskyist leader of Greek origin; leader of the Fourth International; closely involved in supporting the Algerian national liberation struggle against France, which led to imprisonment in the Netherlands in connection with counterfeit money and gun-smuggling activities; a campaign for his release was launched by Jean-Paul Sartre; finally sentenced in 196I to fifteen months imprisonment, released at the end of his trial; took refuge in Morocco; after Algerian independence became minister in the Front de Libération Nationale (FLN) government; in the early i 970 s politically active in Chile under Allende's government; returned to Greece after the fall of the Junta there in 1974 and from 1981 served as Special Advisor to Prime Minister Andreas Papandreou.

Recordings of a three-day discussion in Horefto, a small port in Greece, in July r 995 between the Mexican historian and former Trotskyist Adolfo Gilly and Michel Pablo; these talks cover Pablo's life, political views, and activities, from the I940s, through the Algerian Revolution, the Portuguese Revolution, the Allende experience in Chile, up to the Balkan conflicts of the early I990s, a short contextualizing introduction by Gilly on the circumstances of the interview was added by Sebastian Budgen; recordings of lectures by Adolfo Gilly on the Mexican Revolution of r9ro and the rebellion in Chiapas, Mexico, initiated by the Ejército Zapatista de Liberación Nacional (Zapatista Army of National Liberation) (EZLN), in 1994-1995.

\section{Pereyra Perez, Daniel (born 1927) - Papers \\ Period: 1973-2009 \\ Size: $\mathbf{I}$ m.}

Finding aid: inventory

Born in Buenos Aires, Argentina, 6 October 1927; worker in the graphic industry, later a metalworker; participated in strikes against the military government 1956; elected as trade union representative in the company Siam Di Tella, an important metallurgical and automotive industry in Latin America; board member of the Avellaneda section of the metallurgical workers union; participated in the occupation of the Carma factory 1958 and was imprisoned without trial for two months; sent to Peru by his political party, the Partido Revolucionario de los Trabajadores (PRT), to support the Peruvian peasant movement led by Hugo Blanco; responsible for military actions and for carrying out expropriations to assist in the financing of the peasant movement; arrested after massive occupations of lands and robbing of two banks; tortured in prison and sentenced to seven years; stayed in prison of El Frontón until 1967; returned to Argentina and continued his political militancy in the Santucho group; in 1968, the PRT (Argentina) split into the more theoretical group PRT La Verdad (Nahuel Moreno), and the PRT-El Combatiente (Mario Roberto Santucho), advocating armed struggle; militant and 
board member of the Partido Obrero Revolucionario (POR) since its founding as El Grupo Obrero Revolucionario (GOR); the GOR persisted under the military dictatorship of General Videla; involved in activities of military resistance; smuggled out of Argentina 1978, became a political refugee in Spain and obtained Spanish nationality 1980; member of the Spanish Revolutionary Communist League (LCR), affiliated with the Fourth International; the unification of the LCR with the Moviemento Comunista in 1991 marked the end of the LCR; joined the Izquierda Unida from 1993 until 2008; participated afterwards in the founding of the Espacio Alternativo e Izquierda Anticapitalista; published Argentina rebelde. Crónicas y enseñanzas de la revuelta social (2003), Del Moncada a Chiapas. Historia de la lucha armada en América Latina (2004) and Memorias de un militante internacionalista (2014).

Correspondence with various persons, especially with Roberto Calle 1978-2005; files on Argentina: correspondence, brochures, pamphlets of El Grupo Obrero Revolucionario (GOR) 1975-1987; documents on the Fracción Bolchevique I978-1982; documents on earlier supporters of Juan Posadas (Posadistas) 1977-1984; documents on Partido de Trabajadores Socialistas (PTS), Movimiento al Socialismo (MAS), Horacio Lagar and Raúl Castells I984I999; files on Bolivia: documents on Partido Obrero Revolucionario (POR), a Trotskyist party 1946, 1969-1972; files on Peru: on the support of his Argentinian party Palabra Obrera to the peasant uprising led by Hugo Blanco's Partido Obrero Revolucionario (POR) in Cusco, Peru, 1962-1967 (1983); on Sendero Luminoso (PCP) 1988-1992, on Túpac Amaru Revolutionary Movement (MRTA) 1990-1992, on Patria Roja (PCP) 1997I998, and on the Coordinadora Nacional de Derechos Humanos (CNDDHH) 1983-1993; files on various movements and parties in Spain: Asamblea Alternativa 1990-1991, Izquierda Alternativa 1993-1999, Izquirda Unida 1993-2006, Espacio Alternativo 1995-2007, and Izquierda Anticapitalista 2008-2009; files on organizations of the Argentinian or the Latin American community in Spain: Fracción Latinoamericana (LCR) 19781982, Comité Español de Ayuda al Refugiado (CEAR) I978-I979; Casa Argentina and Centro Argentino de Madrid 1979 and Comisión de Exiliados Argentinos de Madrid (CEAM) I998-1999; files on human rights organizations in Spain like the Asociatión de ex-detenidos desaparecidos 1987-1998, testimonies of political prisoners $1978-1980$, and reports of the Comisión Argentina de Derechos Humanos (CADHU) I978-198 r.

\section{Serand, Patrick (born 1959) - Papers \\ Period: 2018 \\ Size: $0.01 \mathrm{~m}$. \\ Finding aid: inventory}

Accrual: for initial description see: http://hdl.handle.net/10622/ARCHo2936. 
Typescript "Parcours en hétérodoxie. Fragments d'un itinéraire militant". Memories of Patrick Serand with a very detailed description of his activities and the general developments in the Ligue Communiste Révolutionnaire (LCR), the Comités Communistes pour l'Autogestion (CCA), the Confédération Générale du Travail (CGT), and the Alternative Rouge et Verte (AREV). 66 p. 2018.

\section{Zijlstra, Diego (born I879) - Papers \\ Period: c. 1960 \\ Size: $696 \mathrm{MB}$}

Diego Zijlstra was born Dirk or Durk Zijlstra, in Dokkumer Nieuwezijlen in the Netherlands on 2 I June I 879; emigrated in I 889, as a ten-year-old boy, with his parents Taeke Taekes Zijlstra and Mientje Jans Pors on the SS Leerdam to Argentina where free land would be available; Dirk became Don Diego Zijlstra as a farmer and landowner; Zijlstra was co-founder of the colony Cooperativa Rural Limitada Alfa near Tres Arroyos.

Manuscript "Cual ovejas sin pastor" (literally: "Which sheep without a shepherd", but more freely translated: "As sheep without a shepherd") by Diego Zijlstra c.1960.

N.B. There is a published version of this manuscript; this publication Cual ovejas sin pastor (1999) probably differs from the manuscript.

\section{Organizations}

\section{Fondation pour le Dépassement de l'Économie Préhistorique - Archives Period: $1970-1982$ \\ Size $: 0.37 \mathrm{~m}$.}

Finding aid: inventory

The Fondation pour le Dépassement de l'Économie Préhistorique (Foundation for the Passing of the Prehistoric Economy) was founded by Jimmy Lallement and some of his fellow thinkers; themes are the proletarian struggle, the class struggle, and the desirability of a liberated, more equal society in which the old economic mechanisms would have been replaced by a new classless society in which individual freedom and community thinking go together.

Correspondence between Jimmy Lallement, Patrick Tillard, Jordi Vidal, and others 1970-1982; typescripts and other documents on a new society 1970I 980 ; leaflets and other printed matter. 


\section{Fourth International. United Secretariat - Archives \\ Period: 1977-1993 \\ Size: $0.12 \mathrm{~m}$. \\ Finding aid: inventory}

The Fourth International was established in France in 1938 , following the expulsion of Trotsky and his supporters from the Soviet Union; considered the Third International or Comintern as effectively puppets of Stalinism and thus incapable of leading the international working class to political power; consequently, Trotskyists founded their own, competing Fourth International; the Fourth International suffered a major split in 1940 and an even more significant schism in 1953; a partial reunification of the schismatic factions occurred in 1963 , but the organization never recovered sufficiently, and it failed to re-emerge as a single transnational grouping; in 1963 , following a ten-year schism, the majorities of the two public factions of the Fourth International, the International Secretariat, and the International Committee, reunited, electing a United Secretariat of the Fourth International; in 2003, the United Secretariat was replaced by an Executive Bureau and an International Committee, although some other Trotskyists still refer to the organization as the USFI or USec; today, there is no longer a single, centralized cohesive Fourth International.

Minutes of the United Secretariat of the Fourth International 1977-1993; minutes of the Executive Committee of the Fourth International I979-1988; minutes of the XI and XII World Congresses 1980, I985; discussions, reports, and other documents on policy and strategy of the Fourth International I 98 I-I 987.

\section{* International Association of Democratic Lawyers (IADL) - Archives and publications}

Period: 1946-20I I

Size: $2.66 \mathrm{~m}$.

Finding aid: inventory

The International Association of Democratic Lawyers (IADL) was founded in Paris 24 October 1946 by a gathering of lawyers who had survived the war against fascism and participated in the Nuremberg Trials; supported the total ban of nuclear arms; supported the African National Congress Freedom Charter I955; supported the nationalization of the Suez Canal by Egypt I 956 ; called for US withdrawal from Vietnam I 96 I1975; called for freedom for Nelson Mandela 1966-I990; recognized the Palestinian people's rights to self-determination and campaigned for a lasting peace in the Middle East from 1980 on; it is an NGO with consultative status to ECOSOC and UNESCO aiming to facilitate contacts and the exchange of views among lawyers and lawyers' associations of all countries especially by organizing conferences and congresses on long-term national and international issues.

Minutes of annual meetings, meetings of the board and the secretariat, circular letters, and other documents I946-2010; texts by Joë Nordmann and representatives of the Soviet Union on the principles of the IADL and the safeguarding of legality and independence of magistrates [1954]; file on the 
“Comité d'Initiative pour l'Organisation d'une Conférence des Pays d'Europe Occidentale pour l'Amnistie aux Emprisonnés et Exilés Politiques Portugais" and the conference on this theme in Paris on I 5-16 December I962; file on Joë Nordmann 1983-2005; file on the COLAP 5 International Preparatory Meeting ( 5 th Conference of Lawyers in Asia-Pacific) in Manila, Philippines on I 8-i9 September 20I0; bulletins, congress papers, reports on the situation in various countries, periodicals, and other documents published by the IADL I950-2009.

\section{Women's Health Action Foundation (WHAF) - Archives \\ Period: $1993-1998$ \\ Size: $0.37 \mathrm{~m}$. and 3 videotapes}

Finding aid: inventory

Women's Health Action Foundation (WHAF); Amsterdam-based organization supporting a worldwide campaign against anti-pregnancy vaccines; cooperated intensively with the German BUKO (Bundeskongreß entwicklungspolitischer Aktionsgruppen), led by Judith Richter who, in I993, published the report "Impfung gegen Schwangerschaft. Traum der Forscher, Alptraum für Frauen" and initiated the international conference "Vaccination against Pregnancy. Researchers' Dream - Women's Nightmare?" in Bielefeld, Germany, 4-5 June 1993. Other important co-operation partners were the Health Action International (HAI) and the Women's Global Network for Reproductive Rights (WGNRR).

Correspondence, minutes of meetings and conferences, articles, and other documents on the campaign against anti-pregnancy vaccines 1993-1998; three videotapes 1993-I 996 .

\section{Subjects}

International:

PAPA International - Photo Collection

Period: 2006-2016

Size: 3 I.8 GB, I 168 files

Finding aid: list

In 2008, the Amsterdam-based Lino Hellings founded PAPA (Participating Artists' Press Agency); Hellings collaborated with many photographers and taught them to work according to the methods of the PAPA-Photo walk. During the period 20062016, PAPA was active in large cities like Bishkek, Detroit, Dhaka, Lagos, Ramallah, and São Paulo; for instance, PAPA settled down as a temporary office in Ramallah Palestine; this PAPA Lab was hosted by RIWAQ Centre for Architectural Conservation; see also the publication by Lino Hellings, The Making of PAPA Participating Artists Press Agency (2012) and PAPA in Palestine. Critical City Guide Ramallah. A User's Guide about the Tactics of Life (2017). 
I 68 photos taken during photo walks in various countries (Bangladesh, Brazil, Kyrgyzstan, Nigeria, Palestine, and the United States), initiated by PAPA Participating Artists Press Agency 2006-20I6.

\section{China:}

\section{Hong Kong Protest Movement 2019-2020 - Ephemera Collection \\ Period: 2019-2020 \\ Size: $0.25 \mathrm{~m}$.}

Finding aid: list

In 1997, the status of the British crown colony of Hong Kong changed; in consultation with the People's Republic of China, it was agreed that Hong Kong would gradually integrate into the Chinese state model but also remain a Special Administrative Region (SAR) until 2047; 2019 was a troubled year in the Hong Kong Special Administrative Region; protests began in mid-March 2019, prompted by the Extradition Law proposed by the Hong Kong administration; the first major demonstration, on 3I March, was organized by the Civil Human Rights Front (CHRF), founded in 2002, an umbrella organization with dozens of affiliate organizations; the demonstrators made five claims from the outset ("five demands and not one less") including repeal of the Extradition Law, investigation of atrocities committed by the police, release of all protestors, and dismissal of Chief Executive Carrie Lam; the turmoil continued in 2020; by changing the legislation, China is trying to strengthen its grip on Hong Kong.

Small collection of flyers, pamphlets, posters, stickers, and other ephemera and also some objects from the protest movements in Hong Kong 2019-2020.

\section{Egypt: \\ Revolutionary Communist League Egypt - العصبة الثيوعية الثورية (al-'aṣbah al-shuyū 'ìyah al-thawrīyah) - Periodical Collection \\ Period: $1975-1984$ \\ Size: 78 periodicals and 10 pamphlets \\ Finding aid: list}

From the spring of I97I, a number of Marxists attracted to Trotskyism began propaganda activities in student circles in Cairo. In January 1975, the expansion of this activity led to the establishment of al- 'aşbah al-shuyū 'iyah al-thawrīyah (Revolutionary Communist League), which extended its activities to other provinces in the north and south of the country and to a number of major worker sites; the propaganda activities of the Revolutionary Communist League were based on a number of platforms, such as the magazine The Permanent Revolution (1976-1980) and the newspaper What is to be Done? (1979-1984), issued along with a series of translations of texts from the original sources; throughout the extended period from 1972 to 1985 , activists of this current were subjected to arrest and detention because of their activities in student and worker circles. 
Publications (mostly periodicals) of the Revolutionary Communist League -Egypt - العصبة الثنيوعية الثورية (al-'aşbah al-shuyū '̄yah al-thawrīyah) I975I984; well represented in this collection are the periodicals al-thawrah al-dā' imah (الثورة الدائم) I978-1980 and mä al- 'amal? (ما العمل؟) I984) I979.

\section{India:}

\section{All India Trade Union Congress (AITUC) - Archives Size: $46.7 \mathrm{~GB}$}

\section{Finding aid: list}

The All India Trade Union Congress (AITUC) is the oldest trade union federation in India, founded on 3 I October 1920 in Bombay (Mumbai); it was originally allied to the Indian National Congress and was formed to provide representation for India at the League of Nations' International Labour Organization (ILO); among its founders were Lala Lajpat Rai, who became the first President of AITUC, Joseph Baptista, N.M. Joshi, and Diwan Chaman Lall; initially, the AITUC had sixty-four affiliated unions with I40,000 members, and grew to become the largest trade union confederation in India; in the late I920s, the AITUC became more radical, partly under communist influence; a split followed in 1929, and the Indian Trade Union Federation (ITUF) was led by former AITUC president V.V. Giri; AITUC and ITUF merged again in 1939 .

The AITUC played an important role in the struggle for independence; it was also very influential in the foundation of the World Federation of Trade Unions (WFTU) in I945; the AITUC became more associated with the Communist Party of India, but never formally affiliated; its membership has been given as I 4.2 million in $20 \mathrm{I} 3$, making it the third largest trade union confederation in India; the AITUC has its headquarters in New Delhi.

Correspondence, minutes, reports, resolutions, and other documents related to the Congresses, General Council, Working Committee, and the Secretariat of the AITUC 1955-1965.

\section{Southern Africa:}

\section{African Skies Foundation -Video Collection}

Period: 1960-1994

Size: 189 digital tapes, 74 GB, 189 files

Finding aid: inventory

Founded in Amsterdam in 1995 to preserve and manage the extensive video footage and edited productions made between 1982 and 1994 by (the video unit of) the Dutch Anti-Apartheid Movement, which disbanded at the end of 1994; the documentaries were made by Dutch filmmaker Maarten Rens, mostly together with Dutch AAM honorary secretary Fons Geerlings and sometimes in co-operation with the ANC video unit in Lusaka; in 2004, a copy of the collection (in the form of semi-digital tapes) 
was donated to the National Film, Video, and Sound Archive in Pretoria and to the African National Congress archives at the University of Fort Hare in South Africa; in 2015 , the African Skies Foundation was dissolved and the video collection was transferred to the IISH.

The collection consists of almost 190 hours of video footage and edited documentaries produced by the video unit of the Dutch Anti-Apartheid Movement from 1982 to I994; they cover cultural conferences and festivals organized by the Dutch Anti-Apartheid Movement - The Cultural Voice of Resistance, December 1982, and Culture in Another South Africa (CASA), December I 987 - as well as the various forms of aggression by the Apartheid regime in South Africa against the frontline states in Southern Africa and South African exiles (including compilations of items from Angolan and Mozambican television on this subject); also productions on the ANC and the armed struggle, the role of the youth and racism, the exiled South African students at the Solomon Mahlangu Freedom College in Tanzania, and the final gala event of the Dutch AAM in October 1994; this documentary material was augmented with visual items chronicling the activities of the Dutch AAM from I97I to 1994 (among others from Dutch television) and some related miscellaneous film items.

\section{Thailand:}

\section{Thailand - Grey Literature Collection}

\section{Period: $1980-2016$}

Size: $0.25 \mathrm{~m}$.

Finding aid: list

Collection of booklets, brochures, reports from social movements, NGOs (and some government offices) on agriculture, consumers, drugs, economic development, education, environment, ethnic minorities, forests, health, housing, human rights, labor, land reform, law, media, politics, social insurance, students, trafficking, women and youth and children in Thailand, covering the period from the r 980 s until 2016. 